\title{
Aortic Mural Thrombus Associated with Congenital Protein C Deficiency in an Elderly Patient
}

\author{
Kazuki Ueda ${ }^{1}$, Eriko Morishita ${ }^{2}$, Hironaga Shiraki ${ }^{3}$, Shunzo Matsuoka ${ }^{3}$ and Shinsaku Imashuku ${ }^{4}$ \\ ${ }^{1}$ Department of Internal Medicine, Uji-Tokushukai Medical Center, Kyoto, Japan \\ ${ }^{2}$ Department of Clinical Laboratory Science, Kanazawa University Graduate School of Medical Science, Kanazawa, Japan. \\ ${ }^{3}$ Department of Cardiovascular Medicine, Uji-Tokushukai Medical Center, Kyoto, Japan \\ ${ }^{4}$ Department of Laboratory Medicine, Uji-Tokushukai Medical Center, Kyoto, Japan
}

Thrombophilia increases the risk of venous thrombosis, but is rarely responsible for aortic thrombosis. Aortic mural thrombus (AMT) may be associated with a protein $\mathrm{C}$ deficiency. However, it is necessary to determine whether the protein $\mathrm{C}$ deficiency is congenital/hereditary or secondary/acquired (consumption of protein $\mathrm{C}$ during the process of thrombus formation). This study describes a 77-year-old Japanese woman with incidentally diagnosed AMT, who had a protein $\mathrm{C}$ deficiency (activity 54\%, antigen $42 \%$ ). Sequencing of the protein $\mathrm{C}$ gene revealed a heterozygous mutation of c.1268delG, p.Gly423Valfs ${ }^{*} 82$ in exon 9, indicating a congenital protein C deficiency. These findings indicate that very late onset AMT can occur in an adult with congenital protein $\mathrm{C}$ deficiency.

Key words: Aortic mural thrombosis, Protein C deficiency, Congenital thrombophilia

\section{Introduction}

Thrombophilia increases the risk of venous thrombosis, but is rarely responsible for aortic thrombosis. Aortic mural thrombus (AMT), although rare, is a non-aneurysmatic and non-atherosclerotic thrombus of the aortic wall, which can develop in association with primary endothelial disorders, inherited hemostatic disorders, or malignant tumors, or as a complication of heparin therapy ${ }^{1)}$. The most frequent risk factors for the development of AMT include hypercoagulable states or thrombophilic conditions, such as factor $\mathrm{V}$ Leiden mutation and protein $\mathrm{C}$ deficiency $^{2}$. Congenital protein $\mathrm{C}$ deficiency plays a major role in causing AMT, particularly in neonates and infants ${ }^{2,3)}$. AMT in adults may be associated with protein C deficiency either due to congenital genetic mutation or secondary consumption ${ }^{1,4-6)}$. Because AMT in adults may also be related to malignancyassociated hypercoagulable states, it is necessary to determine the precise mechanism(s) causing AMT in individual patients ${ }^{(}$. In addition, various non-cardio- genic thrombo-embolic events can occur in patients with $\mathrm{AMT}^{7}$. This study describes an elderly woman who was incidentally found to have AMT in association with a congenital protein $\mathrm{C}$ deficiency.

\section{Case Report}

A 77-year-old Japanese woman was hospitalized for nausea/vomiting resulting from strangulation ileus caused by ileal adhesion to the bladder diverticulum. Computed tomography angiography (CTA) on admission incidentally revealed AMT in the descending aorta. Regarding the characteristics of AMT, the size (diameter) of AMT site was 30-32 mm while that of the proximal and distal part of descending aorta was measured $30 \mathrm{~mm}$ each. Thorough examination ruled out the possibility of aneurysm; however, we noted some evidence of mild atherosclerosis (Fig. 1). At the age of 68 years, she had been treated for acute heart failure due to aortic and mitral valve regurgitations, but CTA was not performed at that time. Therefore, it was unclear whether her AMT was acute or chronic.

Address for correspondence: Shinsaku Imashuku, Department of Laboratory Medicine, Uji-Tokushukai Medical Center, Uji, 611-0041, Japan

E-mail: shinim95@mbox.kyoto-inet.or.jp

Received: January 8, 2019 Accepted for publication: March 25, 2019

Copyright@2020 Japan Atherosclerosis Society

This article is distributed under the terms of the latest version of CC BY-NC-SA defined by the Creative Commons Attribution License. 


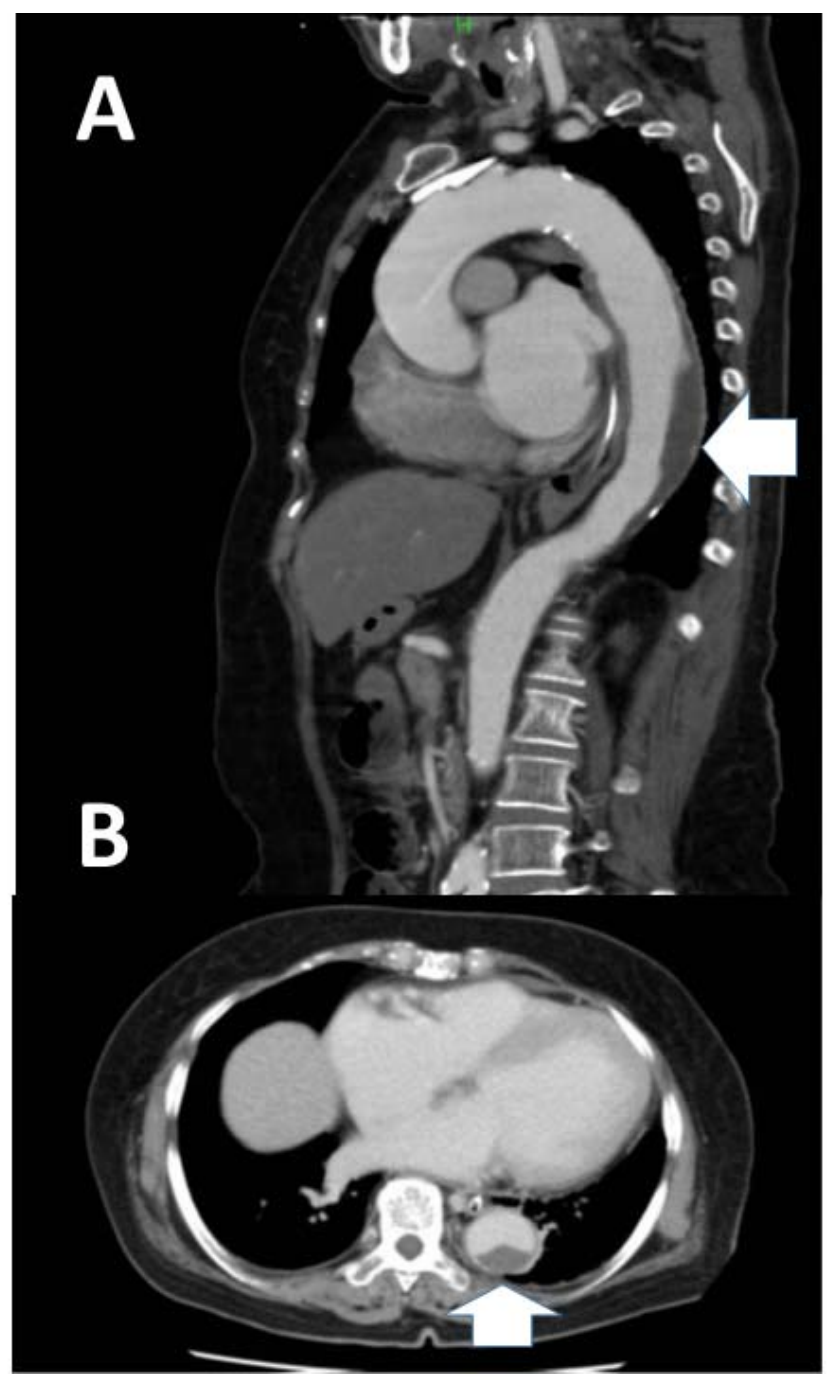

Fig.1.

Enhanced computed tomography (CT) showing a mural thrombus in the descending aorta (arrows). (A) Sagittal view, (B) axial view.

Her systolic blood pressure had been controlled and maintained at around $120 \mathrm{mmHg}$ with use of calcium antagonist/angiotensin II receptor blocker. Her family history (including her mother, three siblings, two children, and two grandchildren) showed no evidence of thrombo-embolic episodes, except for her father who died of brain infarct in his 40s. Her pregnancy/parity history was uneventful, and she had no history of coronary heart disease, thrombo-embolic episodes, bleeding tendencies, any malignancies, diabetes mellitus, or collagen disease. Laboratory data on admission were as follows: White blood cell count, $9,900 / \mu \mathrm{L}$; hemoglobin $(\mathrm{Hb}), 13.9 \mathrm{~g} / \mathrm{dL}$; platelet count, $147,000 / \mu \mathrm{L}$; serum C-reactive protein, $0.02 \mathrm{mg} / \mathrm{dL}$; creatine kinase-MB, 19 IU/L; aspartate aminotransferase, 16 $\mathrm{U} / \mathrm{L}$; alanine aminotransferase, $15 \mathrm{U} / \mathrm{L}$; lactate dehy- drogenase, $233 \mathrm{U} / \mathrm{L}$; total protein, $7.4 \mathrm{~g} / \mathrm{dL}$; albumin, $4.2 \mathrm{~g} / \mathrm{dL}$; blood urea nitrogen, $22.8 \mathrm{mg} / \mathrm{dL}$; creatinine, $0.70 \mathrm{mg} / \mathrm{dL}$; triglyceride, $172 \mathrm{mg} / \mathrm{dL}$; LDLcholesterol, $76 \mathrm{mg} / \mathrm{dL}$; HDL- cholesterol, $62 \mathrm{mg} / \mathrm{dL}$; blood glucose, $132 \mathrm{mg} / \mathrm{dL}$; HbA1C, 5.7\%; and troponin, $<0.03 \mathrm{ng} / \mathrm{mL}$. The patient's coagulation/fibrinolysis and thrombophilia-related data are summarized in Table 1. As shown, the patient had elevated levels of fibrin degradation product (FDP), D-dimer, and thrombin-antithrombin complex (TAT), indicating her hypercoagulable or thrombophilic condition. Assays of protein C showed 54\% activity and 42\% antigen relative to normal, indicating that her AMT was associated with a protein $\mathrm{C}$ deficiency. To determine if this deficiency was congenital, we sequenced her protein $\mathrm{C}$ gene. All interventions were in accordance with the Declaration of Helsinki; the study was approved by the Institutional Review Boards of UjiTokushukai Medical Center and Kanazawa University Graduate School of Medical Science. The patient provided written informed consent. The sequencing results identified a heterozygous mutation of c. $1268 \mathrm{delG}$, p.Gly423Valfs ${ }^{*} 82$ in exon 9 of the protein $\mathrm{C}$ gene, according to the current nomenclature. This mutation was originally described as protein C-Nagoya ${ }^{8)}$, which is relatively common in Japan ${ }^{9)}$. Thus, this patient with a congenital protein $\mathrm{C}$ deficiency developed AMT very late in life.

\section{Discussion}

It is necessary to differentiate AMT from subacute or chronic aortic dissection ${ }^{10)}$ using imaging methods such as CTA, magnetic resonance angiography and, if possible, transesophageal echocardiography. In addition, hemodynamic stability should be evaluated. Our patient was incidentally diagnosed with AMT by CTA, in association with determination of stable hemodynamics. Because of her age, it was likely that AMT was associated with mild atherosclerosis, not with a healthy aorta. Nevertheless, her thrombophilic condition resulting from congenital protein $\mathrm{C}$ deficiency may have played a major role.

A limited number of reports are available to date about the aortic thrombus associated with deficiencies in protein $C$ or protein $S$ in adults ${ }^{1,-6,11)}$. Causes of protein $\mathrm{C}$ and protein $\mathrm{S}$ deficiency were not clearly stated in all these reports. It was thought that the clinical persistence of protein $\mathrm{C}$ deficiency after surgical removal of thrombi may suggest a genetic impairment rather than consumption. Congenital protein $\mathrm{C}$ deficiency was mentioned in 2 reports; in a 49-year-old man with an arterial thrombosis ${ }^{11}$ as well as in a 54-year-old man presented with a mobile aortic 
Table 1. Coagulation/fibrinolysis and thrombophilia-related studies

\begin{tabular}{lc|lc}
\hline PT $(80-100) \%$ & 104 & Protein C activity $(70-100) \%$ & 54 \\
PT-INR $(0.9-1.1)$ & 0.98 & Protein C antigen $(70-150) \%$ & 42 \\
APTT sec & 26.5 & Protein S activity $(70-160) \%$ & 78.3 \\
APTT control sec & 27.7 & Anti-thrombin $(80-130) \%$ & 104 \\
Fibrinogen $(200-400) \mathrm{mg} / \mathrm{dL}$ & 492 & PLg antigen $(9.1-14.5) \mathrm{mg} / \mathrm{dL}$ & 14.7 \\
FDP $(<2.5) \mu \mathrm{g} / \mathrm{mL}$ & 14.7 & ACL-IgG $(<9) \mathrm{U} / \mathrm{mL}$ & 3 \\
D-dimer $(<1.0) \mu \mathrm{g} / \mathrm{mL}$ & 9.0 & LAC $(<7.9) \mathrm{sec}$ & -0.9 \\
Total PAI-1 $(<50) \mathrm{ng} / \mathrm{mL}$ & 33 & Homocysteine $(5.1-11.7) \mathrm{mmol} / \mathrm{mL}$ & 19.5 \\
TAT $(<4.0) \mathrm{ng} / \mathrm{mL}$ & 4.9 & ANA $(<40)$ & $<40$ \\
PIC $(<0.8) \mu \mathrm{g} / \mathrm{mL}$ & 1.4 & MPO-ANCA $(<0.5) \mathrm{IU} / \mathrm{mL}$ & $<0.5$ \\
Factor II $(66-118) \%$ & 122 & PR3-ANCA $(<0.5) \mathrm{IU} / \mathrm{mL}$ & $<0.5$ \\
Factor V $(73-122) \%$ & 121 & Factor IX $(67-152) \%$ & 129 \\
Factor VII $(54-162) \%$ & 116 & Factor X $(58-200) \%$ & 94.5 \\
\hline
\end{tabular}

Abbreviations; TAT $=$ thrombin-antithrombin complex, $\mathrm{PIC}=$ plasmin $\alpha 2$ plasmin inhibitor complex

$\mathrm{PLg}=$ plasminogen, $\mathrm{ACL}=$ anti-cardiolipin, $\mathrm{LAC}=$ lupus anticoagulant, $\mathrm{ANA}=$ anti-nuclear antibody, ANCA $=$ anti-neutrophil cytoplasmic antibody, Values within bracket indicate references.

thrombus and splenic infarction ${ }^{4)}$. However, in other 3 reports, it was unknown if protein $\mathrm{C}$ or protein $\mathrm{S}$ deficiencies were congenital or secondary; in a case of 48-year-old woman with multiple aortic thrombi with protein $\mathrm{C}$ and protein $\mathrm{S}$ deficiencies ${ }^{1)}$, in a case of 39-year-old woman with a floating thrombus in the ascending aorta with protein $\mathrm{C}$ deficiency ${ }^{5)}$ and in a case of 70-year-old man with adult AMT with protein C deficiency ${ }^{6}$. Thus, we think it is worth to report our case of AMT due to congenital protein C deficiency at the oldest age of 77 years.

To date, few molecular genetic studies have assessed for protein $\mathrm{C}$ deficiencies in adult patients with AMT. Our patient was incidentally diagnosed with an aortic thrombus in association with an isolated protein $\mathrm{C}$ deficiency, without episodes of embolism in the central nervous system or heart. No other risk factors for AMT development were found. Genetic sequencing made us possible to directly confirm that her protein $\mathrm{C}$ deficiency was congenital.

Regarding the late onset of congenital disease, one example is familial hemophagocytic lymphohistiocytosis (FHL), for which many late onset cases were described including a case of a 62-year-old patient ${ }^{12,13)}$. In FHL, gene mutation types (missense/nonsense) as well as various environmental factors are assumed to play a role in its disease manifestation. In congenital protein $\mathrm{C}$ deficiency, data were limited and only a few late onset case reports have been found as mentioned above. Thus, it remains unknown why patients develop the disease at different ages and in different blood vessels (venous or aortic). In analogy with FHL, various factors such as surgical stress, infection, dehydration, or atherosclerosis (as noted in this case) could be responsible for the development of thrombosis with underlying congenital protein $\mathrm{C}$ deficiency.

In determining the treatment of AMT in this patient, we were hesitant to perform surgery intervention because of her stable hemodynamics and lack of symptoms. However, surgical intervention is recommended in patients with persistent thrombi and recurrent embolisms ${ }^{14)}$. We also discussed the administration of direct oral anticoagulants; however, it is currently not adaptive for aortic thrombosis. As a result, we chose a close follow-up without any medication.

In summary, the aorta should be included in the organs at risk in patients with thrombophilc conditions. The pathogenesis of aortic thrombus must be carefully evaluated, even in elderly patients. Genetic studies are required if AMT is associated with a protein $\mathrm{C}$ deficiency.

\section{Copyright}

All of the authors listed have contributed to the manuscript, approved final submitted form, have read and agreed to the Editorial Policies of Journal of Atherosclerosis and Thrombosis.

\section{Conflicts of interest}

The authors declare no conflicts of interest.

\section{References}

1) Onwuanyi A, Sachdeva R, Hamirani K, Islam M, Parris R. Multiple aortic thrombi associated with protein $\mathrm{C}$ and S deficiency. Mayo Clin Proc, 2001; 76: 319-322

2) Wieland I, Jack T, Seidemann K, Boehne M, Schmidt F, Happel CM, Koeditz H, Bertram H, Sasse M. Neonatal 
aortic arch thrombosis: analysis of thrombophilic risk factors and prognosis. Cardiol Young, 2014; 24: 33-39

3) Kumar N, Dogra N. An infant with aortoiliac thrombosis due to congenital protein $\mathrm{C}$ deficiency: anesthetic implications. J Clin Anesth, 2012; 24: 506-507

4) Sanon S, Phung MK, Lentz R, Buja LM, Tung PP, McPherson DD, Fuentes F. Floating, non-occlusive, mobile aortic thrombus and splenic infarction associated with protein C deficiency. J Am Soc Echocardiogr, 2009; 22: 1419. e1-3

5) Hisatomi K, Yamada T, Odate T, Yamashita K. Intermittent coronary artery occlusion caused by a floating thrombus in the left coronary sinus of valsalva of a patient with a normal aorta and protein $\mathrm{C}$ deficiency. Ann Thorac Surg, 2011; 92: 1508-1510

6) Yagyu T, Naito M, Kumada M, Nakagawa T. Aortic Mural Thrombus in the Non-Atherosclerotic Aorta of Patients with Multiple Hypercoagulable Factors. Intern Med, 2019; 58: 381-385

7) Verma H, Meda N, Vora S, George RK, Tripathi RK. Contemporary management of symptomatic primary aortic mural thrombus. J Vasc Surg, 2014; 60: 1524-1534

8) Yamamoto K, Tanimoto M, Emi N, Matsushita T, Takamatsu J, Saito H. Impaired secretion of the elongated mutant of protein C (protein C-Nagoya). Molecular and cellular basis for hereditary protein $\mathrm{C}$ deficiency. J Clin Invest, 1992; 90: 2439-2446
9) Sakata T, Kario K, Katayama Y, Matsuyama T, Kato H, Miyata T. Studies on congenital protein C deficiency in Japanese: prevalence, genetic analysis, and relevance to the onset of arterial occlusive diseases. Semin Thromb Hemost, 2000; 26: 11-16

10) Zurick AO, Ramaiah C. Aortic Mural Thrombus in Association with Occult Aortic Dissection. CASE (Phila), 2017; 1: 62-64

11) De Stefano V, Leone G, Micalizzi P, Teofili L, Falappa PG, Pollari G, Bizzi B. Arterial thrombosis as clinical manifestation of congenital protein $\mathrm{C}$ deficiency. Ann Hematol, 1991; 62: 180-183

12) Nagafuji K, Nonami A, Kumano T, Kikushige Y, Yoshimoto G, Takenaka K, Shimoda K, Ohga S, Yasukawa M, Horiuchi H, Ishii E, Harada M. Perforin gene mutations in adult-onset hemophagocytic lymphohistiocytosis. Haematologica, 2007; 92: 978-981

13) Zhang K, Jordan MB, Marsh RA, Johnson JA, Kissell D, Meller J, Villanueva J, Risma KA, Wei Q, Klein PS, Filipovich AH. Hypomorphic mutations in PRF1, MUNC13-4, and STXBP2 are associated with adultonset familial HLH. Blood, 2011; 118: 5794-5798

14) Boufi M, Mameli A, Compes P, Hartung O, Alimi YS. Elective stent-graft treatment for the management of thoracic aorta mural thrombus. Eur J Vasc Endovasc Surg, 2014; 47: 335-341 